\title{
СЕМАНТИКА УКРАЇНСЬКИХ ПАРЕМІЙ
}

\author{
ВАЛЕНТИНА КАЛЬКО \\ Черкаський національний університет імені Богдана Хмельницького, \\ Черкаси - Україна \\ mkalko@ukr.net; ORCID: 0000-0002-9394-1664

\section{SEMANTYKA UKRAIŃSKICH PAREMII} \\ WALENTYNA KALKO \\ Czerkaski Uniwersytet Narodowy imienia Bohdana Chmielnickiego, Czerkasy — Ukraina
}

STRESZCZENIE. Paremia językowa charakteryzuje się specyficznym połączeniem formy i treści, co umożliwia zachowanie, pozyskiwanie, przetwarzanie i transmisję informacji. Semantyka przysłowia motywowana jest strukturą formalną, na podstawie której tworzy się swoista przestrzeń treściowa wypowiedzi. $Z$ jednej strony, znaczenie paremii uwarunkowane jest semantyką czynników, które kreują treść powierzchowną, z drugiej zaś — składniki strukturalne w wielu przypadkach ulegają przekształceniom o charakterze kognitywno-konceptualnym, co powoduje kreowanie zupełnie innej treści.

Słowa kluczowe: paremia, znak językowy, zdanie, semantyka, semantyka głęboka, semantyka powierzchowna.

\section{SEMANTICS IN THE UKRAINIAN LANGUAGE PAROEMIA}

\section{VALENTYNA KALKO \\ Cherkasy Bohdan Khmelnytsky National University, Cherkasy — Ukraine}

ABSTRACT. In the article paroemia is considered as a language sign marked with a special connection of the form and the content that generally is looked upon as a means to preserve, achieve, process and give the information. Proverb semantics is motivated through its formal structure that is originating a meaningful content of the utterance. On the one hand, the proverb meaning is affected by the constituents semantics that generate a surface content, and on the other, in most cases the structural components may be altered both cognitively and conceptually that generally evokes quite a different depth sense.

Key words: paroemia, language sign, utterance, semantics, depth meaning, surface meaning.

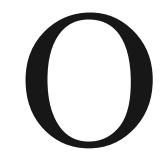

дним із чільних стимулів еволюції знакових засобів мови була життєво важлива потреба у створенні інформаційно містких знаків, здатних зберігати, отримувати, обробляти й передавати якнайбільший обсяг концептуалізованої інформації. Саме до таких специфічних знаків природної мови належать паремії, які відрізняються від інших вербальних знаків передусім тим, що мають багатий культурний зміст, є вираженням самоусвідомлення етносу, каркасом його ментальності, репрезентуючи ії в дискурсах різних типів. Паремії потрібно вивчати з урахуванням трьох аспектів семіозису: семантики, синтактики, прагматики.

Семіотичну природу паремій проаналізовано насамперед в аспекті структуралізму й логічної семантики (Є. Бартмінський, А. Дандес, С. Єрмоленко, Ю. Левін, П. Кавілл, Т. Ніколаєва, Г. Перм’яков, О. Потебня, А. Тейлор, 
Т. Цив'ян та ін.). Описано формальну семантичну структуру прислів'їв, їхній зв'язок з іншими фольклорними жанрами, семіотичну й логічну природу, процеси метафоризації, вияви універсального й національно-специфічного. Так, П. Кавелл уважає, що паремійні одиниці утворюють одну із семіотичних підсистем, яка забезпечує процес повноцінної комунікації. Дослідник кваліфікує їх як знаки-логеми, що „передають специфічну інформацію й мають подібний логічний зміст практично в усіх народів світу, але відрізняються образами (деталями, реаліями), за допомогою яких цей логічний зміст передано" (перекл. автор. - В. К.) $)^{1}$. Однак проектування значення прислів'я на істинну семантику денотата породжує низку суперечливих моментів, пов'язаних із фактором етнічної свідомості в усьому розмаїті їі пізнавальних психічних функцій. Паремія як знак фіксує у відносно стійкій формі специфіку емічної реальності, зберігає колективний рефлексивний досвід народу, стереотипи етносвідомості й архетипи колективного позасвідомого. Прислів'я - водночас і результат, і засіб мовної категоризації й концептуалізації довкілля, ідентифікації, порівняння й упорядкування елементів світу. Належачи до універсуму культури народу, закарбовуючи у своїй знаковій природі практичний, чуттєвий, історичний, соціальний досвід, вони $є$ виявами етнічної й культурної пам'яті, розвитку етносу, чинниками стабілізації, самозбереження мовної системи. Паремійні одиниці фіксують і транслюють від покоління до покоління концептуальний і культурний генотип народу, його морально-етичні й естетичні настанови, норми, ціннісні орієнтації й пріоритети, стереотипи, психологічні й культурні архетипи, міфи, ритуали й вірування, сценарії суспільного життя тощо. Отже, багатий паремійний фонд, виконуючи трансляційну функцію, передає інформацію про специфіку етнічної ментальності, тим самим сприяючи збереженню мови як синергетичної системи.

Поряд із цим специфіку інформативності паремій визначає й процес їхнього створення, що полягає в переведенні семантики зовнішньої форми в глибинний зміст ії тлумачення, оскільки на підставі значення елементів постає новий смисл, більший за обсягом, адже, як зауважує Ф. Растьє, у коловому русі від частини до цілого і в зворотному напрямі глобальний зміст превалює над поверхневим ${ }^{2}$.

Мета статті - описати особливості семантики паремійних знаків як когнітивно-дискурсивного феномена, продукту культури народу, поліфункціонального жанру усної народної творчості.

Зорієнтованість мовознавства к. XX - поч. XXI ст. на вивчення когнітивнодискурсивної природи мовних явищ зумовлює застосування новітніх підходів до аналізу семіотичної сутності прислів'я. Пропонуємо інтерпретувати паремію як мовний знак, що характеризується особливим зв'язком форми й змісту та слугує засобом збереження, отримання, оброблення й передавання інформації. Визнання прислів'я мовним знаком дає змогу, на нашу думку, застосувати семіотичний підхід до його вивчення, загальним принципом якого $є$ урахування трьох взаємопов'язаних і взаємозумовлених компонентів, виокремлених Ч. Моррісом: семантики, синтактики й прагматики. Семантика - відношення знаків до об'єктів, які вони позначають чи можуть позначати, синтактика - це синтаксичні відношення знаків незалежно від їхнього стосунку до об'єктів чи інтерпретатора, прагматика - відношення між знаками та їхніми інтерпретато-

' P. Cavil1, Maxims in Old English Poetry, Cambridge 1999, p. 230.

2 Ф. Р асть е, Интерпретирующая семантика, Нижний Новгород 2001, с. 285. 
рами ${ }^{3}$. У процесі семіозису названі складники $\epsilon$ нероздільними: гармонійна взаємодія цих трьох компонентів забезпечує адекватність передавання й розуміння змісту висловлення.

Першим виміром лінгвосеміозису паремій є семантика, що передовсім умотивована їхньою формальною структурою, на грунті якої виникає своєрідний змістовий простір висловлення. Паремії - етнічно марковані висловлення, тому, описуючи їхню семантику, потрібно враховувати суб'єктивно-культурний чинник, що, власне, на думку С. Бартмінського, і визначає спосіб судження про об'єкт, його категоризацію, вибір ознак для характеристики предмета в конкретних висловленнях і зафіксованих у них значення ${ }^{4}$. Поряд із цим специфіку інформативності паремій визначає й процес їхнього створення, що полягає в переведенні семантики зовнішньої форми в глибинний зміст ії тлумачення, оскільки на підставі значення елементів постає новий смисл, більший за обсягом. 3 одного боку, значення паремії пов'язане із семантикою складників, що утворюють поверхневий зміст, а 3 іншого - у багатьох випадках структурні компоненти зазнають когнітивно-концептуальних перетворень, на підставі чого постає абсолютно інший глибинний зміст.

План змісту паремій як мовних знаків специфічно пов'язаний з планом форми, утіленням якої є прості чи складні речення. Прислів'я структурно організовані у формі речення, а отже, належать до синтаксичних одиниць, оскільки вони є одним із засобів формулювання, вираження й передавання думок, емоцій, відчуттів, почуттів. Ці знаки виконують комунікативну функцію, позаяк використовувані в процесах спілкування, мають структурну, смислову, граматичну й інтонаційну завершеність. Докладний аналіз паремійного репертуару дає змогу констатувати гармонійну єдність інформаційного й виражального елементів, а також досконалу збалансованість семантики з матеріальною формою.

У сучасній лінгвістиці наявні різні підходи до тлумачення значення паремійних висловлень. М. Алефіренко, Л. Буянова, Н. Семененко процес утворення паремій визначають як вторинний семіозис, проектуючи прислів'я на вільні синтаксичні кореляти. Так, М. Алефіренко в структурі значення фразеологічних одиниць, до яких він зараховує й паремії, виокремлює два денотати: денотат-1 - предметна ситуація, буквальне значення; денотат- 2 - переосмислена предметна ситуація; нове, образне значення ${ }^{5}$. На думку дослідника, їхнє накладання й породжує семантичну невизначеність фразеологічних одиниць. Проте виокремлення двох денотатів уже суперечить структурі знака, оскільки не відображає всіх закономірностей семіозису, адже прислів'я різняться за способами зв'язку семантики компонентів інтегрального характеру.

Поліпарадигмальний простір сучасного мовознавства забезпечує пояснення паремійного семіозису в проекції на неоднорідну природу етносвідомості й створену нею емічну реальність. О. Потебня пояснював значення стійких висловлень на підставі семантики й структури вільного синтаксичного корелята як підгрунтя втілення нового значення саме в такій, а не іншій формі ${ }^{6}$. В. Телія слушно зауважує, що співвідношення стійких й ідіоматичних конструкцій 3 їхніми вільними (чи гіпотетично можливими) аналогами було методологічним виміром як у класичному, так і в посткласичному періодах розвитку фразе-

3 Ч. Морри с, Основания теории знаков, [в:] Семиотика, Москва 1983, с. 43-62.

${ }^{4}$ J. B a rtmińs ki, Językowe podstawy obrazu świata, Lublin 2006, s. 78.

${ }^{5}$ Н. Ф. Алефиренко, Фразеологическое значение: природа, сущңность, структура, [в:] Грани слова, сб. науч. ст. к 65-летию проф. В. М. Мокиенко, Москва 2005, с. 22-25.

${ }^{6}$ А. А. Потебня, Теоретическая поэтика, Москва 1990, с. 101-136. 
ологічної науки, хоча вже на першому етапі з'явилися ідеї, пов'язані з поясненням значення сталих висловлень незалежно від лексичного контексту ${ }^{7}$. Пошуки вільного синтаксичного корелята досить часто призводять до нехтування в процесах паремійного семіозису різноманітними операціями свідомості, що не завжди вибудувані синтаксично в номінативній структурі цих досить специфічних мовних знаків. У сучасних пареміологічних дослідженнях усе більше уваги закцентовано на асоціативно-образному поєднанні мовних знаків у структурі прислів'їв (А. Баранов, Д. Добровольський, Ж. Колоїз, Т. Космеда, О. Селіванова та ін.). Так, А. Баранов і Д. Добровольський уважають, що значення цілого неможливо вивести зі значення складників за стандартними правилами семантичної сполучуваності, адже семантика формується на грунті асоціацій, що загалом можуть бути не пов'язані ні з прямим значенням, ні з метафоричними моделями ${ }^{8}$. Специфіка знакової природи паремій зумовлена комбінаторною мотивованістю: „сполучення слів забезпечує не суму їхніх смислів у позначуваному, а створення нового смислу"9.

Оскільки прислів'я - це знаки-висловлення, їхня семантика безпосередньо пов'язана зі значенням складників. Більшість учених уважає, що загальна семантика речення - це комплекс взаємопов'язаних смислів, виражених не лише компонентами його структури, а й синтаксичними відношеннями та зв'язками між цими складниками. Проте беззаперечним є те, що форма речення не становить простої суми граматичних форм слів, які, вступаючи в синтаксичні відношення, утворюють якісно нову лінгвістичну одиницю, властивості якої не рівнозначні сумі властивостей слів, що належать до структури висловлення.

Тому в семантиці паремійних висловлень можна виокремити два рівні: з одного боку, поверхневе значення, виведене на грунті аналізу мовних фактів і закономірностей із семантики окремих складників, а $з$ іншого - глибинне, тобто той зміст, який постає на основі мовних значень, асоціацій, уявлень, оцінок тощо. В. Телія нечіткість денотативного значення фразеологічних одиниць пов'язує з позамовними чинниками чи екстралінгвальною інформацією. Дифузність денотативного змісту опосередкована образним підгрунтям метафори, залучення якого до структур знань про позначуване спричинює збільшення "подробиць” у самому значенні ${ }^{10}$. Дослідниця зауважує, що „образна мотивація, навіть якщо вона стерлася, усе ж таки встигає в процесі номінації наділити денотат такими деталями, які, по суті, розмивають чітке категорійне підгрунтя типового уявлення" (перекл. автор. - В. К.) ${ }^{11}$.

Саме в паремійних знаках як малих жанрах фольклору зосереджені всі можливі когнітивні процеси, притаманні етносу. Паремія — це складний мовний знак із дифузною семантикою, глибинні структури якої співвідносні з різними видами знання - енциклопедичного, фонового, соціального, історичного, культурного тощо, адже в їхньому значенні відображено зафіксовані в етнічній свідомості звичаї, обряди, традиції, повір'я, побут, релігійні уявлення. 3 позицій когнітивної лінгвістики паремійне значення є надбанням мовної свідомості, багатовимірним комплексом, різні смисли якого проходять крізь фільтр менталь-

\footnotetext{
${ }^{7}$ В. Н. Телия, Русская фразеология: семантический, прагматический и лингвокультурологический аспекты, Москва 1996, с. 12-13.

${ }^{8}$ А. Н. Баранов, Д. О. Добровольский, Идиоматичность и идиомы, [в:] „Вопросы языкознания", 1996, № 5, с. 52.

${ }^{9}$ О. О. С елі в ан о в а, Світ свідомості в мові. Мир сознания в языке, Черкаси 2012, с. 172.

${ }^{10}$ В. Н. Телия, указ. источ., с. $150-151$.

${ }^{11}$ Там же, с. 163.
} 
ності мовців і зазнають інтерпретації в просторі соціального й культурного знання. Паремія як знакова форма ментальних репрезентацій - результат сприйняття людиною себе й довкілля, тому когнітивна сутність ії семантики не обмежена синтезом і комбінаторикою змісту складників. Значення прислів'я передовсім пов'язане з певною концептуальною структурою - одиницею, що „об'єднує вербальну й невербальну інформацію, набуту шляхом сприйняття й усвідомлення ситуації, дії, явища, ознаки, предмета тощо п'ятьма психічними функціями: відчуттями, почуттями, мисленням, інтуїцією, трансцендентністю"12. В. Телія наголошує: „Очевидно, що звукова оболонка виконує знакову функцію лише за умови ії асоційованості з позначуваним фрагментом немовного типу; ця асоціація й $\epsilon$ тим, що в мовознавстві - у різних його напрямах - називають значенням"(перекл. автор. - В. К. ${ }^{13}$.

Прислів'я в семантичному аспекті є унікальними мовними утвореннями, значення яких здебільшого виводяться внаслідок інтеграції двох і більше смислових структур. У паремійних висловлень унаслідок образного осмислення типових життєвих ситуацій створюється єдиний ментальний простір, що виражає культурно зумовлений зміст розуміння довкілля. Відображаючи символізацію соціальної діяльності етносу, ці одиниці у своїй семантиці експлікують ціннісні координати, засадничі для української культури онтологічні категорії, фрагменти концептосфери. Вони є продуктом культурно-гносеологічної здатності етносу фіксувати як стереотипне власне антропометричне ставлення до об'єктивного світу, що з часом перетворюється на прототипне в етносвідомості. Психологічне підгрунтя паремійної стереотипізації становить „прагнення людини вилучити з наявної ситуації усе, що в ній $є$ корисного, і відкласти про запас у вигляді рухливої звички вироблену в такому випадку реакцію, щоб використати їі в ситуаціях такого самого типу"14. Уважаємо, що особливістю вербалізації семантики паремійних одиниць $є$ пряме значення, але їхня образність і виразність уможливлюють двоїстість мовної структури, що, власне, й забезпечує декодування й передавання змісту, оскільки не розкодоване не підлягає ретрансляції.

Пояснення семантики паремійних одиниць у класичній фразеології якраз і здійснюють методом аплікації на грунті зв'язку зі значенням і структурою вільного синтаксичного корелята як основи творення прислів'я з урахуванням способу вираження ідеї, який зумовив появу нового значення (див. праці Ш. Баллі, В. Виноградова, В. Жукова, О. Куніна, О. Потебні, Л. Скрипник та ін.). 3 огляду на особливості структури й змісту компонентів можна відзначити, що деякі паремії мають вільний синтаксичний корелят, напр.: Без води млин не меле; Кому що, а мельнику вітер; Без кліщів гарячого заліза не візьмеш; Без лопати не покопаєш, без грабель не погребеш; Без стовпчиків і тин не стоятиме; Без відлиги сніг не розтане. Однак буквальний зміст вільного синтаксичного корелята, беззаперечно, не збігається зі змістом самих прислів'їв, які мають значення 'для досягнення певного результату потрібні відповідні умови, зусилля'. У такому разі відбувається переплавлення змісту складників паремійного знака, переосмислення ситуації, трансформація вихідного значення. Однак не всі прислів'я мають вільний синтаксичний корелят порівн.: Дорога на кіниі язика — 'щоб не блудити, треба питати дороги'; Добре ковадло не боїться молотка - 'загарто-

${ }^{12} \mathrm{O}$. О.С е лі в ан о в а, Нариси з украӥнської фразеології (психокогнітивний та етнокультурний аспекти), Київ-Черкаси 2004, с. 19.

${ }^{13}$ В. Н. Телия, указ. источ., с. 84.

${ }^{14}$ О. О. Селі в ан о в а, Лінгвістична енциклопедія, Полтава 2010, с. 768. 
вана в життєвій борні людина здатна витримати удари долі'; Коваль коня кує, а жаба ногу підставляє - 'про гордого, зарозумілого, який хоче зрівнятися з таким, що стоїть від нього набагато вище розумом, спритністю’.

У більшості паремійних знаків поверхневий зміст має суто організаційне призначення й на підставі своєї образної природи зазнає перекодування. Для розуміння семантики паремійного висловлення потрібна інтерпретація його глибинного семантичного змісту, що відбувається на грунті аналізу пропозицій, реалізованих у поверхневій структурі. Уважаємо, що на рівні глибинної семантики прислів'я містить основні кванти знань, що вказують на побутові, соціальні, культурно-історичні, етичні тощо чинники формування цих знаків. Підгрунтя механізму утворення значення паремійних одиниць становить явище функційної самоорганізації мови, яке й передбачає, що їхня семантика виникає не внаслідок складання значень компонентів, а як новий синергійний глибинний зміст, нетотожний простій сумі значень цих елементів. Так, у висловленні На кропиву колючу $і$ мороз тріскучий ядерні пропозиційні структури представлені суб'єктами донорських доменів РОСЛИНА і ПРИРОДНЕ ЯВИЩЕ та Якісними показниками (колючий, тріскучий), що мають негативну конотацію. Метафорична переінтерпретація створює надзвичайно виразні образи, і на підставі асоціативного поєднання двох ситуацій виникає семантика 'поганого, лихого, злого настигне кара'. У прислів'ї Горе тобі, воле, коли тебе корова рогом коле закцентовано увагу на сценарії поведінки тварин, представленого пропозиційними структурами, пов'язаними причинно-наслідковими відношеннями суб'єкта, об'єкта, предиката й партитива. Цей сценарій переінтерпретовує ситуацію стосунків між чоловіком і дружиною домену ЛЮДИНА: предикат коло$m u$, що вказує на ступінь інтенсивності дії, спрямованої від суб'єкта на об'єкт, і партитив ріг за рахунок метафоричного осмислення ситуації передають буквальну інформацію 'жінка керує чоловіком'. Метафорична інтеграція пов'язана 3 тим, що для українців бик (віл) - 'символ мужності, хоробрості' ${ }^{15}$, тому уособлює чоловіка, а корова - 'джерело добробуту та багатства', у фольклорі асоціюється із жінкою"'16. Можемо стверджувати, що прислів’я висміює недолугих, безхарактерних чоловіків, якими керують жінки.

Отже, за традиційними уявленнями, головою української сім'ї є чоловік. Натомість у прислів'ях Бика голова не боліла, як корова теля родила; Чиї бики, аби мої телята; Чий бугайчик був, аби тільки телятко було наме; У вола голова не боліла, коли корова теля родила зоометафори бик, віл, корова, теля символізують батька, матір, дитину і, відповідно, передають ставлення батьків-чоловіків до дітей. Це дає підстави встановити, що в наївній свідомості українців укорінено уявлення, що батько, на відміну від матері, яка народжує дитину, не так любить їі і дорожить нею.

Оскільки прислів'я зорієнтоване на колективного адресата, а метафора ускладнює розуміння змісту висловлення, то у формальній структурі паремійних знаків досить продуктивно репрезентовано елементи пропозиційного статусу, що, інтегруючись із асоціативними конституентами, сприяють розкодуванню глибинної семантики й полегшують інтерпретацію значення. Такі прислів'я найбільш поширені, їхня вербальна структура спроектована на пропозиційну інформацію і іiі метафоричну переінтерпретацію, інтегруючи пропозиційний компонент з асоціативно-термінальним у структурі знань про позначува-

\footnotetext{
${ }^{15}$ В. М. В ойтович, Украӥнська міфологія, Київ 2005, с. 516.

${ }^{16}$ Там само, с. 528.
} 
не. Зміст таких паремій можна дешифрувати внаслідок зіткнення об'єктивного, буквального з неістинним, фігуральним. Так, у висловленнях Вітер йому свище в голові; Вітер свище в голові поєднано два різновиди пропозиційних структур: метафоричні знаки донорського домену ПРИРОДНЕ ЯВИЩЕ суб'єкТ вітер і предикат свище корелюють з пропозицією домену ЛЮДИНА, представленого локативом в голові. У результаті інтеграції двох позиційних схем прислів'я набуває здатності позначати легковажну, непостійну людину, що часто змінює свої уподобання. У паремії Молодість - пташкою, старість - черепашкою позиційна схема представлена пропозиціями буквального змісту, вербалізованих знаками темпоративів (молодість і старість), опосередкованими імпліцитними предикатами руху, а також фігурально вираженими пропозиціями, що корелюють 3 ядерною на підставі знаків 3 донорських доменів ПТАХ і ТВАРИНА, які передають якість темпоративів домену ЛЮДИНА. Унаслідок метафоричної переінтерпретації паремія набуває значення 'молодість швидкоплинна, а старість тривала'.

За авторськими спостереженнями, найбільшу продуктивність у процесі метафоризації в складі прислів'їв мають партонімічні компоненти - соматизми людини, по-перше, через загальну антропоцентричність паремійного фонду, по-друге, через значущість чуттєвої царини в пізнанні первісною людиною довкілля, адже за допомогою органів відчуття „відбувається процес пізнання навколишнього світу і тих органів, за допомогою яких здійснюються найрізноманітніші дії і процеси" ${ }^{\prime 7}$. Паремії із соматизмами язик, рот через уподібнення до метафоричних термів донорського домену АРТЕФАКТ (язика - до млина, молота, рота - до воріт, хліва, городу) здебільшого позначають мовленнєву діяльність індивіда. Метафоризація цих компонентів модифікує загальне значення й пристосовує до певної позиції в концепті ЛЮДИНА, порівн.: Не всі клепають молотком, деякі і язиком; Не мели язиком поза очима; Язик у роті, мели, щзо хочеш; Коло чужсго рота не поставиш ворота; Чужий рот - не свої ворота, не зачиниш; Чужий рот - не хлів, не зачиниш; Рот - не город, не загородиш; Рот - не ворота, клином не запреш. Соматизм ніс уподібнюється до гострого предмета, пов'язаного зі значенням негативно оцінюваних допитливості чи безцеремонного втручання в чужі справи, напр.: Встромляти свого носа в чужсий город; В чуже просо не пхай носа; Не сунь свого носа в чуже просо. Також піднятий вгору ніс є стереотипом пихи, погорди, зарозумілості, надмірної впевненості у своїх силах, здібностях, можливостях: Задер носа - $i$ кочергою не дістанеш; Ніс у нього задрався, щоб не задрипався; Не піднімай носа вище голови, бо вкоротять. Метафорична переінтерпретація пов'язує погляд людини з вогнем із метою створення інтегральної семантики 'дивитися гнівно, люто, сердито', порівн.: 3 очей іскри посипалися; Іскри з очей полетіли; 3 очей іскри скачуть або з процесом споживання їжі, напр.: Мало його очима не з'їв; Очима би мене з'їв для передавання значення 'дивитися дуже уважно, пильно'. Проектуючи чуттєво сприйняті ситуації на абстрактні, концептуальна метафора слугує дієвим засобом пізнання, з'ясування, умотивування, позначення ситуації, не пов'язаної з безпосереднім фізичним досвідом, а отже, виконує когнітивну функцію.

У висловленні Часом і між кропивою лілія росте глибинний зміст виникає в результаті використання гештальтів донорської зони РОСЛИНА (кропива, лілія), спроектованих на реципієнтний домен ЛЮДИНА, що дає змогу пояснити

\footnotetext{
${ }^{17}$ Л. Г. С кр ипн ик, Фразеологія украӥнської мови, Київ 1973, с. 102-103.
} 
семантику паремії: 'між лютих, недоброзичливих, жорстоких, злих людей трапляються ніжні, добрі, м’які, красиві'. Значне метафоричне навантаження припадає на предикати, адже дієслово є центром події і семантика його позначень стає концептуальним фільтром перетворення буквальної інформації на фігуральну. Складне поєднання метафорики предикатів, персоніфікація суб'єкта донорського домену АРТЕФАКТ представлені в прислів'ї Пішов глечик за водой ma й сів на дно. Декодування цілісного глибинного змісту 'хто прагне до чогось, може постраждати' відбувається на підставі ситуацій, позначених присудками.

Отже, план змісту паремії є символічним, подвійно прихованим за формою, адже „мова є предметним обстоюванням буття, і обстоюванням - смисловим, точніше - виразним, і ще точніше - символічним" (перекл. автор. - В. К.) $)^{18}$. У поліпарадигмальному просторі сучасної лінгвістики пояснення значення паремії потрібно здійснювати на грунті реконструкції структури знань про позначуване з урахуванням інтеграції різних психічних функцій свідомості, iі синергетичного зв'язку із соціумом і культурою етносу, а також зважаючи на загальні семіотичні закономірності мови. Прислів'я як знаковий засіб зберігає різноманітні форми знань про світ: пропозиційні, образні, гештальтні, аксіологічні, архетипні, міфологічні тощо, які з'являються під час сприйняття довкілля, виникають в актах пізнання, відображають й узагальнюють людський досвід й омовлену в процесі взаємодії зі світом дійсність. Тому зміст паремійних одиниць є багатошаровою структурою, співвідносною з усім обсягом знань про позначуване, у їхній когнітивній структурі репрезентовано окремі компоненти, по-перше, ті, що потрібні для ідентифікації семантики висловлення; по-друге, потенційні ознаки, логічно вивідні із загального знання про позначуване; потретє, асоціативні ознаки, що відображають взаємодію позначуваного з іншими об'єктами довкілля; по-четверте, етнокультурні ознаки, що віддзеркалюють національну специфіку осягнення, структурування, категоризації фізичного й психічного довкілля.

Процедура розкодування змісту прислів'я — це складний когнітивний механізм, підгрунтям якого є неоднорідна, дифузна семіотична форма і структура знань про компоненти, які використано у висловленні. Процес тлумачення семантики паремії передбачає декодування буквальної інформації, вираженої знаками відповідної пропозиції, фігуральної інформації, репрезентованої метафоричними знаками донорських доменів, що інтегровані в структуру знань індивіда про певну подію, ситуацію, явище, факт, предмет тощо. Глибинний зміст прислів"їв умотивований експлікованістю в їхній семантиці засадничих для української етнокультури онтологічних категорій, фактів національної концептосфери, ціннісної інформації.

\section{Список використаної літератури}

Алефиренко Н. Ф., Фразеологическое значение: природа, сущность, структура, [в:] Грани слова, сб. науч. ст. к 65-летию проф. В. М. Мокиенко, Москва 2005.

Баранов А. Н., Добровольский Д. О., Идиоматичность и идиомы, [в:] „Вопросы языкознания", 1996, № 5, с. 51-64.

Войтович В. М., Українська міфологія, Київ 2005.

Лосев А. Ф., Философия имени, Москва 1990.

Моррис Ч., Основания теории знаков, [в:] Семиотика, Москва 1983.

Растье Ф., Интерпретирующая семантика, Нижний Новгород 2001.

${ }^{18}$ А. Ф. Лос ев, Философия имени, Москва 1990, с. 98. 
Селіванова О. О., Лінгвістична енциклопедія, Полтава 2010.

Селіванова О. О., Нариси з украӥнської фразеології (психокогнітивний та етнокультурний аспекти), Київ-Черкаси 2004.

Селіванова О. О., Світ свідомості в мові. Мир сознания в языке, Черкаси 2012.

Скрипник Л. Г., Фразеологія української мови, Київ 1973.

Телия В. Н., Русская фразеология: семантический, прагматический и лингвокультурологический аспекты, Москва 1996.

Потебня А. А., Теоретическая поэтика, Москва 1990.

Bartmiński J., Językowe podstawy obrazu świata, Lublin 2006.

Cavill P., Maxims in Old English Poetry, Cambridge 1999.

\section{Spysok vykorystanoi literatury [References]}

Alefirenko N. F., Frazeologicheskoe znachenie: priroda, sushhnost', struktura [Phraseological Meaning: Nature, Essence, Structure], [v:] Grani slova, sb. nauch. st. k 65-letiyu prof. V. M. Mokienko, Moskva 2005.

Baranov A. N., Dobrovol'skij D. O., Idiomatichnost' $i$ idiomy [Idiomatic Phenomenon and Idioms], [v:] „Voprosy yazykoznaniya”, 1996, № 5, s. 51-64.

Voitovych V. M., Ukrainska mifolohiia [Ukrainian Mythology], Kyiv 2005.

Losev A. F., Filosofiya imeni [Philosophy of Name], Moskva 1990.

Morris Ch., Osnovaniya teorii znakov [Fundamentals of Theory of Languages], [v:] Semiotika, Moskva 1983.

Rast'e F., Interpretiruyushhaya semantika [Interpretative Semantics], Nizhnij Novgorod 2001.

Selivanova O. O., Linhvistychna entsyklopediia [Linguistic Encyclopedia], Poltava 2010.

Selivanova O. O., Narysy z ukrainskoi frazeolohii (psykhokohnityvnyi ta etnokulturnyi aspekty) [Sketches on Ukrainian Phraseology (Psycho-cognitive and Ethno-Cultural Aspects)], Kyiv-Cherkasy 2004.

Selivanova O. O., Svit svidomosti v movi. Myr soznanyia vyazike [World of Consciousness in Language], Cherkasy 2012.

Skrypnyk L. H., Frazeolohiia ukrainskoi movy [The Ukrainian Language Phraseology], Kyiv 1973.

Teliya V. N., Russkaya frazeologiya: semanticheskij, pragmaticheskij i lingvo-kul'turologicheskij aspekty [The Russian Language Phraseology: Semantic, Pragmatic and Linguo-culturological Aspects], Moskva 1996.

Potebnya A. A., Teoreticheskaya poet ika [Theoretical Poetics], Moskva 1990.

Bartmiński J., Językowe podstawy obrazu świata [Language Fundamentals of World Image], Lublin 2006.

Cavill P., Maxims in Old English Poetry, Cambridge 1999. 